\title{
Upaya Peningkatan Hasil Belajar Siswa Melalui Model Pembelajaran Creative Problem Solving Pada Materi Menerapkan Etika Komunikasi Bisnis SMK Negeri 1 Banda Aceh
}

\author{
Husna \\ SMK Negeri 1 Kota Banda Aceh \\ Email : husna.smk1@gmail.com \\ Doi : 10.32672/jsa.v7i5.1513
}

\begin{abstract}
ABSTRAK
Keterkaitan antara pengetahuan yang diperoleh siswa dengan kehidupan nyata yang mereka hadapi sangat membantu dalam proses pembelajaran siswa, terutama untuk siswa kelas satu sekolah menengah kejuruan. Karenanya peneliti merasa perlu memilih pendekatan pembelajaran yang dapat meningkatkan minat belajar dan pemahaman siswa yaitu model pembelajaran Creative Problem Solving (CPS). Penelitian ini bertujuan untuk mendeskripsikan penerapan model pembelajaran Creative Problem Solving (CPS) yang dapat meningkatkan hasil belajar siswa kelas XI SMK Negeri 1 Banda Aceh pada materi menerapkan etika komunikasi bisnis. Penelitian ini menggunakan pendekatan kualitatif dengan menggunakan jenis penelitian tindakan kelas. Subjek penelitian adalah siswa kelas XI SMK Negeri 1 Banda Aceh berjumlah 25 siswa. Data dalam penelitian ini berupa lembar observasi guru dan siswa, hasil belajar siswa dan angket respon siswa. Teknik pengumpulan datanya adalah soal tes dan lembar observasi guru, aktivitas siswa dan angket respon siswa. Teknik analisis data menggunkan analisis deskriptif untuk menganalisis data aktivitas siswa dan guru, hasil belajar siswa dianalisis dengan analisis ketuntasan. Persentase ketuntasan hasil belajar siswa pada siklus I adalah $84,65 \%$ dan siklus II adalah 100\%. Peningkatan hasil belajar siswa adalah sebanyak 15,35\%. Berdasarkan hasil yang diperoleh pada siklus I dan siklus II dapat disimpulkan bahwa model pembelajaran Creative Problem Solving (CPS) dapat meningkatkan hasil belajar siswa kelas XI SMK Negeri 1 Banda Aceh pada materi menerapkan etika komunikasi bisnis.
\end{abstract}

Kata Kunci: Creative Problem Solving, Hasil Belajar, Etika Komunikasi

\section{PENDAHULUAN}

Pembelajaran merupakan suatu proses perubahan yang dilakukan individu untuk memperoleh suatu perubahan prilaku yang baru secara keseluruhan, sebagai hasil dan pengalaman individu itu sendiri dalam berinteraksi dengan lingkungannya. Pentingnya pembelajaran menurut Dimyati dan Mudjiono (2005:38), mengatakan bahwa: "Pembelajaran pada dasarnya merupakan upaya pendidikan untuk membantu siswa 
melakukan kegiatan belajar. Tujuan pembelajaran adalah untuk membekali siswa dengan pengetahuan yang nanti akan terwujudnya efisiensi dan efektifitas kegiatan belajar yang dilakukan peserta didik. Sehingga pemahaman siswa terhadap suatu persoalan tidak terhenti pada suatu titik jawaban saja". Nurhadi (2003:20) mengemukakan beberapa konsep sebagai implementasi dari teori kontruktivisme dalam praktek pembelajaran di sekolah-sekolah kita sekarang antara lain: (1) balajar adalah proses pemaknaan informasi baru, (2) kebebasan unsur exensial dalam lingkungan belajar, (3) strategi belajar yang digunakan menentukan proses dan hasil belajar, (4) belajar pada hakikatnya memiliki aspek social dan budaya, (5) kerja kelompok dianggap sangat berharga.

Komunikasi bisnis merupakan salah satu pelajaran yang diajarkan di sekolah menengah kejuruan. Pengertian komunikasi bisnis menurut Purwanto (2006:4) Komunikasi bisnis adalah komunikasi yang digunakan dalam dunia bisnis yang mencakup berbagai macam bentuk komunikasi baik komunikasi verbal maupun nonverbal untuk mencapai tujuan tertentu. Pengertian komunikasi bisnis menurut Katz (1994:4) Komunikasi Bisnis adalah adanya pertukaran ide, pesan, dan konsep yang berkaitan dengan pencapaian serangkaian tujuan komersil. Komunikasi bisnis merupakan salah satu ilmu yang bersifat khas dibandingkan dengan ilmu lainnnya yaitu lebih menekankan untuk berfikir logis, komunikasi bisnis juga memiliki peranan dalam mempelajari bidang studi ilmu sosial. Dengan demikian sudah selayaknya komunikasi bisnis diajarkan kepada siswa sejak tingkat sekolah menengah kejuruan hingga perguruan tinggi. Meskipun komunikasi bisnis sangat penting, namun kenyataan banyak siswa yang kurang mampu memecahkan masalah komunikasi bisnis. Hal itu dapat disebabkan karena salah satu karakteristik komunikasi bisnis yang bersifat abstrak, sifat abstrak ini menyebabkan banyak siswa mengalami kesulitan dalam memahami komunikasi bisnis.

Jenning dan Dunne (Purnama, 2007:2) menyatakan bahwa: Kebanyakan siswa mengalami kesulitan dalam mengaplikasikan komunikasi bisnis ke dalam situasi kehidupan real, kesulitan ini dapat disebabkan karena dalam proses pembelajaran di kelas guru tidak mengaitkan antara materi pelajaran dengan kehidupan real yang dihadapi siswa, siswa hanya memahami apa yang disampaikan guru dalam bentuk abstrak, selain itu siswa juga tidak dilibatkan secara langsung dalam proses pembentukan pengetahuan, pengetahuan baru diperoleh siswa dari penjelasan guru dan pengetahuan bersifat hapalan. Keterkaitan antara pengetahuan yang diperoleh siswa dengan kehidupan nyata yang mereka hadapi sangat membantu dalam proses pembelajaran siswa, terutama untuk siswa kelas sebelas Sekolah Menengah Kejuruan (SMK). Siswa akan sangat lebih tertarik mempelajari materi yang langsung dapat mereka lihat dalam bentuk nyata, bukan sekedar gambar-gambar atau penjelasan yang diberikan guru. Berdasarkan pengalaman peneliti sebagai guru yang mengajar mata pelajaran komunikasi bisnis di SMK Negeri 1 Banda Aceh, diketahui bahwasanya minat siswa untuk mengikuti pembelajaran komunikasi bisnis masih sangat rendah. Hal ini dapat dilihat dari hasil beljar siswa sebagian besar tidak mencapai Kriteria Ketuntasan Minimal (KKM) yang telah ditetapkan di sekolah tersebut. Menurut Anwar (2005:89) mengemukakan tentang hasil belajar bila dilihat dari tujuannya yaiu mengungkapkan keberhasilan seseorang dalam belajar. Di mana hasil belajar tersebut memiliki beberapa faktor yang sangat mempengaruhi keberhasilan di dalam proses pembelajaran. Slameto (2005:56) mengatakan bahwa: "Faktor yang mempengaruhi belajar banyak jenisnya, tetapi 
dapat digolongkan menjadi dua golongan saja, yaitu faktor internal dan factor eksternal. Faktor internal adalah faktor yang ada dalam diri individu sedangkan faktor eksternal adalah faktor yang berada diluar individu".

Peneliti selama dalam melaksanakan pembelajaran komunikasi bisnis masih menerapkan pembelajaran konvensional, yaitu pembelajaran dengan cara ceramah dan menjadikan siswa sebagai objek dalam pembelajaran. Sehingga siswa hanya mendengarkan penjelasan dari guru dan menuliskan apa yang tertulis di papan tulis. Membuat siswa kurang berminat dalam mengikuti proses belajar mengajar, pemahaman siswa dalam belajar tidak bertahan lama karena pengetahuan yang deperoleh lebih bersifat hapalan, bukan pemaknaan terhadap pengetahuan yang diperoleh. Oleh karenanya peneliti merasa perlu melakukan perbaikan cara mengajar dengan cara memilih pendekatan pembelajaran yang bisa meningkatkan minat belajar dan pemahaman siswa.

Salah satu pendekatan pembelajaran yang dapat meningkatkan minat belajar dan pemahaman siswa adalah pembelajaran yang menghubungkan antara materi ajar dengan kehidupan dan pengalaman sehari-hari siswa yaitu model pembelajaran Creative Problem Solving (CPS). Model pembelajaran yang disingkat CPS ini merupakan suatu model pembelajaran yang memusatkan pada pengajaran dan ketrampilan pemecahan masalah, yang diikuti dengan penguatan ketrampilan. Ketika dihadapkan dengan suatu pertanyaan, siswa dapat melakukan keterampilan memecahkan masalah untuk memilih dan mengembangkan tanggapannya. Tidak hanya dengan cara menghafal tanpa dipikir, keterampilan memecahkan masalah memperluas proses berpikir, Pepkin (2004:35). Ada beberapa karakteristik creative problem solving (CPS), menurut Steiner, (2009:97) yaitu sebagai berikut: a. Dalam menyelesaikan suatu problem, dimulai dari proses recursive (pengulangan), revised (peninjauan kembali), dan redefined (pendefinisian ulang). $b$. Memerlukan proses berpikir divergen dan konvergen. c. Menggagas suatu pemikiran yang bersifat prediktif serta dapat merangsang ke tahap berpikir logis selanjutnya. Dengan menggunakan model pembelajaran ini diharapkan dapat menimbulkan minat sekaligus kretivitas dan motivasi siswa dalam mempelajari komunikasi bisnis, sehingga siswa dapat memperoleh manfaat yang maksimal, baik dari proses maupun hasil belajarnya.

\section{METODE PENELITIAN}

Penelitian ini dilaksanakan di SMK Negeri 1 Banda Aceh Tahun Pelajaran 2016/2017.Pelaksanaan penelitian ini berlangsung pada semester ganjil yang direncanakan akan berjalan pada Bulan Agustus-Oktober 2016, tahun pelajaran 2016/2017. Subjek penelitian ini adalah siswa kelas XI SMK Negeri 1 Banda Aceh dengan jumlah siswa 25 orang. Penelitian tindakan kelas ini dilakukan dalam dua siklus tindakan. Siklus pertama akan sangat menentukan siklus berikutnya. Tiap siklus terdiri dari 4 tahap yaitu: 1) perencanaan, 2) pelaksanaan, 3) pengamatan, dan 4) refleksi. penulis menggunakan alat pengumpul data sebagai berikut: 1) lembar observasi/pengamatan, 2) tes hasil belajar, 3) Angket. Teknik analisis data pada penelitian ini disajikan dengan beberapa tahapan yakni: 1) Analisis data kemampuan guru mengelola pembelajaran, 2) Analisis data aktifitas siswa, 3) Analisis membandingkan hasil Belajar Siswa, dan 4) Analisis angket dengan menggunakan analisis deskriptif dengan persentase. 
Husna

\section{HASIL PENELITIAN DAN PEMBAHASAN \\ Siklus Pra Tindakan}

Pembelajaran yang telah berlangsung selama ini, peneliti melaksanakannya secara konvensioanal. Guru (peneliti) lebih aktif dibandingkan siswa, dengan menjadikan siswa sebagai objek dalam pembelajaran. Sehingga kemampuan siswa dalam menguasai materi pelajaran sedang.

Berdasarkan hasil tes prasiklus didapatkan bahwa rerata nilai siswa dari 25 orang adalah 53,88. Kriteria Ketuntasan Minimal yang ditentukan adalah 75. Siswa yang tuntas adalah sebanyak 10 siswa dan yang tidak tuntas adalah 15 siswa. Bila dipersenkan, maka persentase jumlah siswa yang telah tuntas adalah $40 \%$. Siswa yang tidak tuntas persentasenya adalah 60\%. Sehingga dapat disimpulkan dengan KKM 75, hasil belajar siswa masih rendah.

\section{Siklus I}

a. Perencanaan

Pada tahap perencanaan, peneliti mempelajari kurikulum sekolah kelas XI, membuat silabus yang sesuai dengan materi yang akan diajarkan, merancang Rencana Pelaksanaan Pembelajaran (RPP) yang berisi skenario pembelajaran yang mengacu pada penggunaan model CPS. Membuat Lembar Aktivitas Siswa (LAS), karena LAS berperan sebagai pemandu siswa dalam melaksanakan tugas belajar. Kemudian membuat tes siklus untuk mengetahui hasil belajar siswa. Peneliti merencanakan sebaik mungkin agar tujuan pembelajaran dapat dicapai.

b. Pelaksanaan

Pelakasanaan pada siklus I ini sesuai dengan yang telah dituliskan pada rencana pelaksanaan pembelajaran. Pembelajaran ini dilakukan dengan alokasi waktu sekali pertemuan ( 2 x 45 menit). Pertemuan ke-I dilakukan pada tanggal 20 Agustus 2016 dengan materi pokok menerapkan etika komunikasi bisnis dalam sub pokok bahasan pengertian komunikasi, pengertian komunikasi bisnis, tujuan dan fungsi komunikasi bisnis. Sedangkan pertemuan ke-2 dilakukan pada tanggal 22 Agustus 2016 dengan materi menerapkan etika komunikasi bisnis dalam sub pokok bahasan proses komunikasi, unsurunsur komunikasi, dan bentuk komunikasi. Pertemuan ketiga dilaksanakan pada 24 Agustus 2016, pada pertemuan ini diadakan tes siklus I dengan alokasi waktu 2 x 45 menit. Hasil tes siswa dapat dilihat pada tabel di bawah ini.

Tabel 1. Hasil Tes Siklus I

\begin{tabular}{|c|l|c|c|}
\hline No & \multicolumn{1}{|c|}{ Nama } & Nilai & Keterangan \\
\hline 1 & Aditya Nursilkhah & 80 & Tuntas \\
\hline 2 & Ana Sopiyanti Maharani & 70 & Tuntas \\
\hline 3 & Andista Rohani Sofian & 80 & Tuntas \\
\hline 4 & Cut Rifka Wiranda & 80 & Tuntas \\
\hline 5 & Dwi Juliyanti & 60 & Tidak tuntas \\
\hline 6 & Fera Afriyani & 70 & Tuntas \\
\hline 7 & Hardiana & 70 & Tuntas \\
\hline 8 & Hasnati & 80 & Tuntas \\
\hline
\end{tabular}




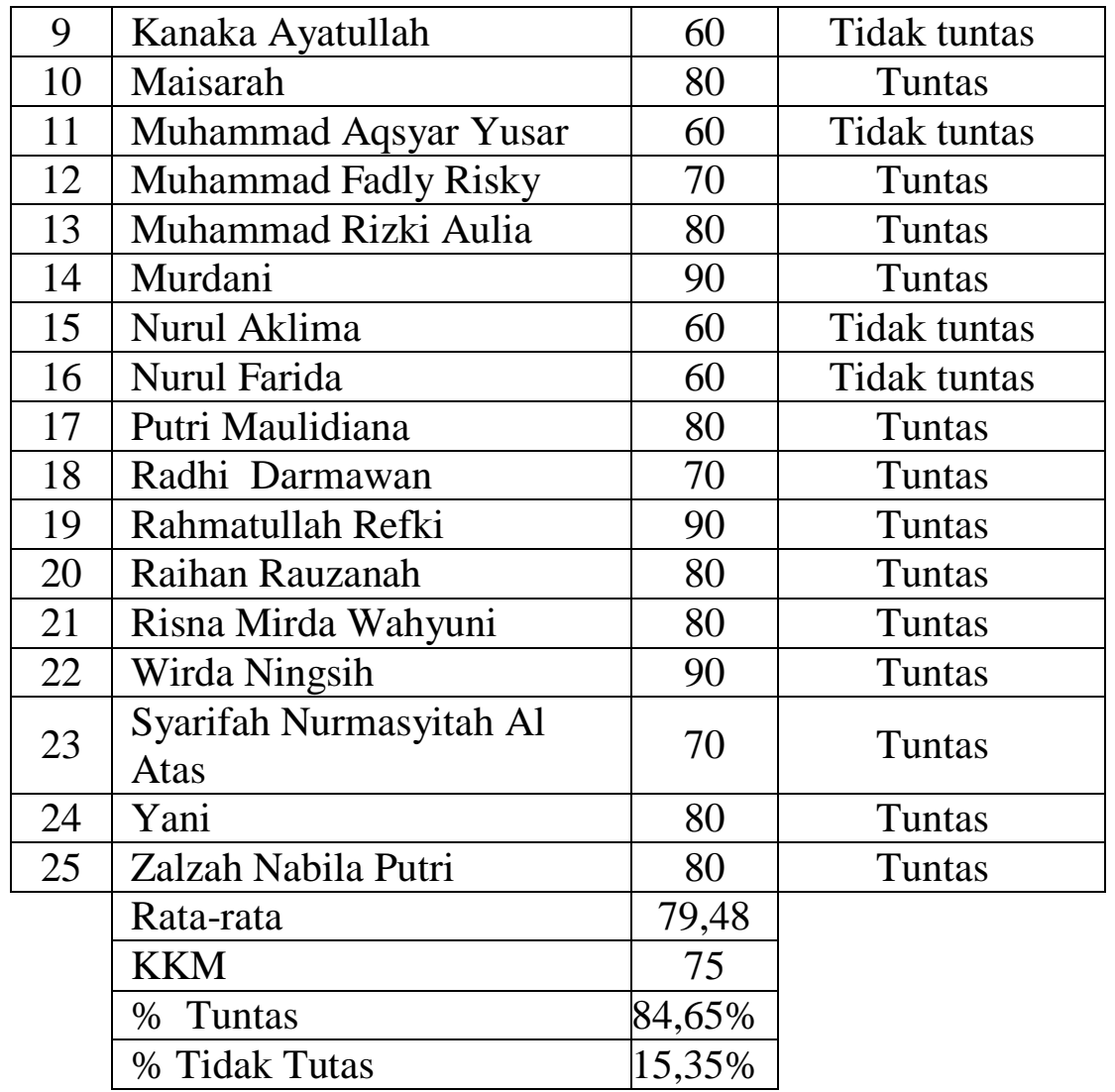

Berdasarkan tabel di atas, dari 25 siswa yang mengikuti tes diperoleh bahwa 20 siswa (80\%) tuntas mengikuti pembelajaran dengan pembelajaran CPS pada materi etika komunikasi, selebihnya 5 siswa $(20 \%)$ tidak tuntas karena nilai yang diperoleh $<75$. Hal ini dapat disimpulkan bahwa pembelajaran dengan pembelajaran CPS pada etika komunikasi belum mencapai ketuntasan secara klasikal, karena terdapat $\leq 85 \%$ siswa belum tuntas tuntas secara individu.

\section{c. Observasi}

Pada tahap ini, observe melaksanakan pengamatan secara langsung terhadap aktifitas guru dan aktifitas siswa selama pembelajaran berlangsung. Berikut hasil observasi aktivitas guru pada siklus I.

Tabel 2. Observasi Aktivitas Guru Siklus I

\begin{tabular}{|c|c|c|c|c|}
\hline NO & Aspek Yang Diamati & RPP I & RPP II & Rata-rata \\
\hline 1. & \multicolumn{4}{|l|}{ Pendahuluan: } \\
\hline & a. Kemampuan melakukan apersepsi & 3 & 4 & 3,5 \\
\hline & $\begin{array}{ll}\text { b. Kemampuan memotivasi siswa dan mengkomunikasikan } \\
\text { tujuan pembelajaran }\end{array}$ & 4 & 5 & 4,5 \\
\hline & $\begin{array}{lll}\text { c. } & \begin{array}{l}\text { Kemampuan langkah-langkah } \\
\text { pembelajaran yang digunakan }\end{array} & \\
\end{array}$ & 4 & 5 & 4,5 \\
\hline 2. & \multicolumn{4}{|l|}{ Kegiatan Inti: } \\
\hline & a. Kemampuan menjelaskan materi & 4 & 5 & 4,5 \\
\hline
\end{tabular}


Husna

\begin{tabular}{|c|c|c|c|c|}
\hline & $\begin{array}{l}\text { b. Kemampuan mengarahkan siswa untuk bekerja sama dalam } \\
\text { kelompok menemukan jawaban soal, dengan memberikan } \\
\text { bantuan terbatas }\end{array}$ & 4 & 5 & 4,5 \\
\hline & $\begin{array}{l}\text { c. Kemampuan cara mengamati cara siswa menyelesaikan } \\
\text { soal/masalah }\end{array}$ & 4 & 5 & 4,5 \\
\hline & $\begin{array}{ll}\text { d. } & \text { Kemampuan mengoptimalkan interaksi siswa dalam bekerja }\end{array}$ & 4 & 4 & 4 \\
\hline & e. Kemampuan memimpin diskusi kelas/menguasai kelas & 4 & 5 & 4,5 \\
\hline & $\begin{array}{l}\text { f. Kemampuan mendorong siswa untuk menanggapi hasil } \\
\text { presentasi kelompok lain }\end{array}$ & 3 & 4 & 3,5 \\
\hline & $\begin{array}{l}\text { g. Kemampuan mendorong siswa untuk mau bertanya, } \\
\text { mengeluarkan pendapat atau menjawab pertanyaan. }\end{array}$ & 4 & 4 & 4 \\
\hline & h. Kemampuan menghargai pendapat berbagai siswa & 4 & 4 & 4 \\
\hline & i. Kemampuan mengajukan dan menjawab pertanyaan & 4 & 4 & 4 \\
\hline 3. & \multicolumn{4}{|l|}{ Penutup: } \\
\hline & 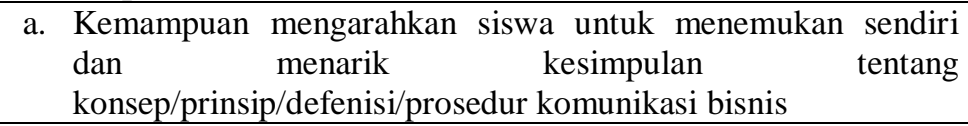 & 4 & 5 & 4,5 \\
\hline & $\begin{array}{l}\text { b. Kemampuan menegaskan hal-hal penting intisari berkaitan } \\
\text { dengan pembelajaran }\end{array}$ & 4 & 5 & 4,5 \\
\hline & $\begin{array}{lllll}\text { c. } & \begin{array}{l}\text { Kemampuan menyampaikan } \\
\text { berikutnya/menutup Pelajaran }\end{array} & \text { judul } & \text { sub } & \text { materi } \\
\end{array}$ & 4 & 5 & 4,5 \\
\hline 4. & Kemampuan Mengelola Kelas & 4 & 4 & 4 \\
\hline 5. & \multicolumn{4}{|l|}{ Suasana Kelas } \\
\hline & a. Antusias siswa & 4 & 5 & 4,5 \\
\hline & b. Antusias Guru & 5 & 5 & 5 \\
\hline & Rata-rata Keseluruhan & \multicolumn{3}{|c|}{4,28} \\
\hline
\end{tabular}

Berdasarkan tabel hasil observasi dilapangan nampak bahwa nilai keseluruhan aktivitas guru dalam mengelola pembelajaran pada siklus I adalah 4,28. Berdasarkan TKG (Tingkat Kemampuan Guru) dapat disimpulkan bahwa pembelajaran siklus I berada pada taraf baik. Hasil observasi aktivitas siswa pada siklus I diuraikankan pada tabel di bawah ini.

Tabel 3. Observasi Aktivitas Siswa Siklus I

\begin{tabular}{|c|c|c|c|c|c|}
\hline \multirow[b]{2}{*}{ Aspek Pengamatan Aktivitas Siswa } & \multirow[b]{2}{*}{ RPP I } & \multirow[b]{2}{*}{ RPP II } & \multirow[b]{2}{*}{$\begin{array}{c}\text { Rata-rata } \\
(\%)\end{array}$} & \multicolumn{2}{|c|}{ Persentase Kesesuaian (P) } \\
\hline & & & & $\begin{array}{c}\text { Waktu } \\
\text { Ideal }\end{array}$ & Toleransi \\
\hline $\begin{array}{l}\text { Mendengar/memperhatikan } \\
\text { guru/teman }\end{array}$ & 10,4 & 10,4 & 10,4 & $13 \%$ & $7 \% \leq \mathrm{P} \leq 18 \%$ \\
\hline $\begin{array}{l}\text { membaca/memahami masalah kontekstual di } \\
\text { LKS }\end{array}$ & 11,45 & 9,37 & 10,41 & $10 \%$ & $5 \% \leq \mathrm{P} \leq 15 \%$ \\
\hline $\begin{array}{l}\text { Menyelesaikan masalah atau menemukan } \\
\text { solusi pemecahan masalah }\end{array}$ & 19,79 & 23,96 & 21,88 & $27 \%$ & $22 \% \leq \mathrm{P} \leq 32 \%$ \\
\hline $\begin{array}{l}\text { Membandingkan hasil temuan diskusi } \\
\text { kelompok dengan hasil diskusi kelompoknya }\end{array}$ & 25 & 26,04 & 25,52 & $30 \%$ & $25 \% \leq \mathrm{P} \leq 35 \%$ \\
\hline $\begin{array}{l}\text { Bertanya/menyampaikan pendapat/ide kepada } \\
\text { guru atau teman sekelompok }\end{array}$ & 12,5 & 12,5 & 12,5 & $10 \%$ & $5 \% \leq \mathrm{P} \leq 15 \%$ \\
\hline $\begin{array}{l}\text { Menarik kesimpulan suatu konsep yang } \\
\text { ditemukan atau suatu prosedur yang dikerjakan }\end{array}$ & 11,46 & 12,5 & 11,98 & $10 \%$ & $5 \% \leq \mathrm{P} \leq 15 \%$ \\
\hline Perilaku yang tidak relevan dengan KBM & 5,21 & 3,13 & 7,29 & $0 \%$ & $0 \% \leq \mathrm{P} \leq 5 \%$ \\
\hline
\end{tabular}


Berdasarkan tabel di atas diketahui bahwa beberapa aktivitas siswa telah mengacu pada kriteria waktu ideal aktivitas siswa dalam pembelajaran. Kecuali aspek menyelesaikan masalah atau menemukan solusi pemecahan masalah dan aspek perilaku yang tidak relevan dengan KBM berada di luar toleransi waktu yang diberikan. Sehingga disimpulkan bahwa aktivitas siswa pada siklus I tidak aktif.

d. Refleksi

Berdasarkan hasil observasi di lapangan pada tindakkan pembelajaran siklus I, masih banyak kekurangan yang dilakukan guru, diantaranya: 1. Kurangnya kemampuan guru memotivasi siswa, sehingga ada siswa yang tidak termotivasi untuk mengikuti proses pembelajaran. 2. Kurangnya kemampuan guru mengontrol proses pembelajaran, sehingga ada siswa yang tidak mengikuti proses pembelajaran dengan betul-betul. 3. Kemampuan prasyarat siswa masih kurang, sehingga ada beberapa siswa yang belum siap dan belum paham. 4. Ada kegiatan siswa selain diskusi pelajaran yang tidak terperhatikan dan ada kelompok yang kurang paham cara mengerjakan LAS. Hasil refleksi pada siklus I merupakan catatan untuk peneliti agar pada pertemuan berikutnya tidak mengulangi kekurangan pada pertemuan sebelumnya dan melakukan perbaikan. Selanjutnya dilakukan tindakan pembelajaran sebagai berikut: 1. Peneliti berusaha untuk memotivasi siswa dengan menampakkan gambar-gambar yang berbentuk memahami relasi dan fungsi. 2. Peneliti harus lebih aktif dalam mengontrol suasana belajar, agar semua siswa mengikuti pembelajaran dengan baik. 3. Peneliti berusaha memperjelas pengetahuan prasyarat siswa, maupun pembahasan materi secara sistematis dan intensif sehingga diharapkan semua siswa memahami langkah-langkah yang harus dilakukan dalam pembelajaran dan materi yang diberikan mulai dari awal sampai pembuatan rangkuman cukup jelas. 4. Pada diskusi kelompok, peneliti membimbing masing-masing siswa setiap kelompok secara merata sehingga semua kelompok bisa paham cara mengerjakan LAS.

\section{Siklus II}

\section{a. Perencanaan}

Pada perencanaan tahap kedua merupakan tahap perbaikan dari siklus I. peneliti mempersiapkan bahan-bahan yang diperlukan untuk melaksanakan siklus II. Yaitu mempelajari kurikulum sekolah kelas XI, membuat silabus, merancang Rencana Pelaksanaan pembelajaran, Lembar Aktivitas Siswa, dan membuat tes siklus II. Diharapan akan adanya perbaikan hasil belajar siswa dengan menerapkan pembelajaran menggunakan pendekatan kooperatip tipe CPS. Peneliti juga harus menyiapkan hal-hal yang diperlukan untuk memperbaiki kekurangan pada siklus I.

\section{b. Pelaksanaan}

Pelakasanaan pada siklus I ini sesuai dengan yang telah dituliskan pada rencana pelaksanaan pembelajaran. Pembelajaran ini dilakukan dengan alokasi waktu sekali pertemuan ( 2 x 45 menit).Pertemuan pertama siklus II dilaksanakan pada tanggal 11 September 2016. Sub pokok bahasan yang diajarkan adalah macam-macam komunikasi, dan faktor keberhasilan komunikasi. Pertemuan kedua pada siklus II dilaksanakan pada 
Husna

tanggal 15 September 2016 guna melaksanakan tes siklus II. Hasil tes siswa dapat dilihat pada tabel di bawah ini.

Tabel 4. Hasil Tes Siklus II

\begin{tabular}{|c|c|c|c|}
\hline No & Nama & Nilai & Keterangan \\
\hline 1 & Aditya Nursilkhah & 90 & Tuntas \\
\hline 2 & Ana Sopiyanti Maharani & 90 & Tuntas \\
\hline 3 & Andista Rohani Sofian & 80 & Tuntas \\
\hline 4 & Cut Rifka Wiranda & 80 & Tuntas \\
\hline 5 & Dwi Juliyanti & 78 & Tuntas \\
\hline 6 & Fera Afriyani & 80 & Tuntas \\
\hline 7 & Hardiana & 90 & Tuntas \\
\hline 8 & Hasnati & 100 & Tuntas \\
\hline 9 & Kanaka Ayatullah & 80 & Tuntas \\
\hline 10 & Maisarah & 90 & Tuntas \\
\hline 11 & Muhammad Aqsyar Yusar & 80 & Tuntas \\
\hline 12 & Muhammad Fadly Risky & 80 & tuntas \\
\hline 13 & Muhammad Rizki Aulia & 100 & Tuntas \\
\hline 14 & Murdani & 90 & Tuntas \\
\hline 15 & Nurul Aklima & 78 & Tuntas \\
\hline 16 & Nurul Farida & 80 & Tuntas \\
\hline 17 & Putri Maulidiana & 90 & Tuntas \\
\hline 18 & Radhi Darmawan & 80 & Tuntas \\
\hline 19 & Rahmatullah Refki & 90 & Tuntas \\
\hline 20 & Raihan Rauzanah & 80 & Tuntas \\
\hline 21 & Risna Mirda Wahyuni & 90 & Tuntas \\
\hline 22 & Wirda Ningsih & 100 & Tuntas \\
\hline 23 & $\begin{array}{l}\text { Syarifah Nurmasyitah } \mathrm{Al} \\
\text { Atas }\end{array}$ & 90 & Tuntas \\
\hline 24 & Yani & 100 & Tuntas \\
\hline 25 & Zalzah Nabila Putri & 90 & \\
\hline & Rata-rata & 87,04 & \\
\hline & KKM & 75 & \\
\hline & $\%$ Tuntas & $100 \%$ & \\
\hline & $\%$ Tidak Tutas & $0 \%$ & \\
\hline
\end{tabular}

Berdasarkan tabel di atas, dari 25 siswa yang mengikuti tes diperoleh bahwa seluruh siswa (100\%) tuntas mengikuti pembelajaran dengan pembelajaran CPS pada materi bentuk komunikasi dan faktor keberhasilan komunikasi, hal ini dapat disimpulkan bahwa pembelajaran dengan pembelajaran CPS pada materi bentuk komunikasi dan faktor keberhasilan komunikasi sudah mencapai ketuntasan secara klasikal, karena terdapat $\geq 85$ siswa tuntas secara individual dan mengalami peningkatan dibandingkan dengan siklus I. 
Serambi Akademica

Jurnal Pendidikan, Sains, dan Humaniora
Vol. 7, No. 5,

Oktober 2019
pISSN 2337-8085

eISSN 2657- 0998

c. Observasi

Pada tahap ini, observe melaksanakan pengamatan secara langsung terhadap aktifitas guru dan aktifitas siswa selama pembelajaran berlangsung. Berikut hasil observasi aktivitas guru pada siklus II.

Tabel 5. Observasi Aktivitas Guru Siklus II

\begin{tabular}{|c|l|c|}
\hline NO & \multicolumn{1}{|c|}{ Aspek Yang Diamati } & RPP III \\
\hline 1. & Pendahuluan: & 4 \\
\hline & a. Kemampuan melakukan apersepsi & 5 \\
\hline & b. Kemampuan memotivasi siswa dan mengkomunikasikan tujuan pembelajaran & 5 \\
\hline & c. Kemampuan menginformasikan langkah-langkah pembelajaran yang digunakan & 5 \\
\hline 2. & Kegiatan Inti: & 5 \\
\hline & a. Kemampuan menjelaskan materi & 5 \\
\hline & b. Kemampuan mengarahkan siswa untuk bekerja sama dalam kelompok menemukan & 5 \\
\hline & c. Kemaban soal, dengan memberikan bantuan terbatas & 5 \\
\hline & d. Kemampuan mengoptimalkan interaksi siswa dalam bekerja & 4 \\
\hline & e. Kemampuan memimpin diskusi kelas/menguasai kelas & 4 \\
\hline & f. Kemampuan mendorong siswa untuk menanggapi hasil presentasi kelompok lain & 5 \\
\hline & g. Kemampuan mendorong siswa untuk mau bertanya, mengeluarkan pendapat atau & 5 \\
\hline & h. Kenjawab pertanyaan. & 4 \\
\hline & i. Kemampuan mengajukan dan menjawab pertanyaan & 5 \\
\hline 3. & Penutup: & 5 \\
\hline & $\begin{array}{l}\text { a. Kemampuan mengarahkan siswa untuk menemukan sendiri dan menarik } \\
\text { kesimpulan tentang konsep/prinsip/defenisi /prosedur komunikasi bisnis }\end{array}$ & 5 \\
\hline & b. Kemampuan menegaskan hal-hal penting intisari berkaitan dengan pembelajaran \\
\hline c. Kemampuan menyampaikan judul sub materi berikutnya/menutup Pelajaran & 5 \\
\hline $\mathbf{5 .}$ & Kemampuan Mengelola Kelas & 5 \\
\hline & Suasana Kelas $\quad$ Antusias siswa & 5 \\
\hline & d. Antusias Guru & 5 \\
\hline
\end{tabular}

Berdasarkan tabel hasil observasi di atas diketahui bahwasanya aspek pada siklus I yang belum terlaksana dengan sempurna, pada siklus II telah mengalami peningkatan. Seperti aspek kemampuan melakukan apersepsi, mengoptimalkan interaksi siswa, mendorong siswa untuk mengeluarkan pendapat, bertanya maupun menjawab pertanyaan dan juga kemampuan peneliti megelola kelas. Secara keseluruhan pada siklus II semua aspek mengalami peningkatan. Berdasarkan TKG (Tingkat Kemampuan Guru) Dapat disimpulkan bahwa pembelajaran siklus II berada pada taraf sangat baik dengan rata-rata keseluruhan 4,68. Hasil observasi aktivitas siswa pada siklus II diuraikankan pada tabel di bawah ini. 
Tabel 6. Observasi Aktivitas Siswa Siklus II

\begin{tabular}{|l|c|c|c|}
\hline \multirow{2}{*}{ Aspek Pengamatan Aktivitas Siswa } & \multirow{2}{*}{ RPP III (\%) } & \multicolumn{3}{c|}{\begin{tabular}{c} 
Persentase Kesesuaian (P) \\
\cline { 3 - 4 }
\end{tabular}} & & Waktu & Toleransi \\
\hline Mendengar/memperhatikan penjelasan guru/teman & 10,9 & $13 \%$ & $7 \% \leq \mathrm{P} \leq 18 \%$ \\
\hline membaca/memahami masalah kontekstual di LKS & 13,54 & $10 \%$ & $5 \% \leq \mathrm{P} \leq 15 \%$ \\
\hline $\begin{array}{l}\text { Menyelesaikan masalah atau menemukan solusi } \\
\text { pemecahan masalah }\end{array}$ & 25 & $27 \%$ & $22 \% \leq \mathrm{P} \leq 32 \%$ \\
\hline $\begin{array}{l}\text { Membandingkan hasil temuan diskusi kelompok dengan } \\
\text { hasil diskusi kelompoknya }\end{array}$ & 27,08 & $30 \%$ & $25 \% \leq \mathrm{P} \leq 35 \%$ \\
\hline $\begin{array}{l}\text { Bertanya/menyampaikan pendapat/ide kepada guru } \\
\text { atau teman sekelompok }\end{array}$ & 10,42 & $10 \%$ & $5 \% \leq \mathrm{P} \leq 15 \%$ \\
\hline $\begin{array}{l}\text { Menarik kesimpulan suatu konsep yang ditemukan atau } \\
\text { suatu prosedur yang dikerjakan }\end{array}$ & 10,94 & $10 \%$ & $5 \% \leq \mathrm{P} \leq 15 \%$ \\
\hline Perilaku yang tidak relevan dengan KBM & 2,08 & $0 \%$ & $0 \% \leq \mathrm{P} \leq 5 \%$ \\
\hline
\end{tabular}

Berdasarkan hasil pengamatan di lapangan di atas diketahui bahwa semua aktivitas siswa telah mengacu pada kriteria waktu toleran yang diberikan. Secara umum dapat disimpulkan bahwa aktivitas siswa selama mengikuti pembelajaran pada siklus II dengan menggunakan pembelajaran CPS sudah aktif.

\section{d. Refleksi}

Berdasarkan observasi pada tindakkan pembelajaran siklus II, diketahui telah banyak mengalami peningkatan, hal ini bisa dilihat dari nilai siswa pada siklus II mengalami peningkatan dibandingkan dengan siklus I. Untuk kemampuan memotivasi dan mengontrol suasana belajar sudah berjalan dengan baik. Pada umumnya secara keseluruhan pada siklus II telah mengalami peningkatan.

\section{Angket Respon Siswa}

Dari angket respon siswa yang diisi oleh 25 siswa setelah mengikuti pembelajaran untuk materi etika komunikasi dengan model CPS, maka diperoleh hasil dengan rincian seperti berikut.

Perasaan siswa terhadap komponen guru mengajar, dari aspek materi pelajaran 100 persen sisswa merasa senang, aspek LKS 87 persen siswa merasa senang, aspek tes hasil belajar 100 persen siswa merasa senang, suasana pembelajaran di kelas 87 persen siswa merasa senang, dan cara guru mengajar 100 persen siswa merasa senang. Mengenai kebaruan komponen pembelajaran, dari aspek materi pelajaran 100 persen siswa merasa baru, aspek LKS 93 persen merasa baru, aspek tes hasil belajar 80 persen siswa merasa baru, aspek uasana pembelajaran di kelas 80 persen siswa merasa baru, dan aspek cara guru mengajar 100 persen siswa merasa baru dalam hal cara guru mengajar.

Berdasarkan kriteria pada bab III, tabel di atas menunjukkan bahwa respon siswa terhadap pembelajaran komunikasi bisnis dengan menggunakan model pembelajaran CPS adalah positif, dan siswa berminat untuk mengikuti pembelajaran berikutnya. 
Serambi Akademica

Jurnal Pendidikan, Sains, dan Humaniora
Vol. 7, No. 5,

Oktober 2019
pISSN 2337-8085

eISSN 2657- 0998

\section{PENUTUP}

\section{Simpulan}

Berdasarkan hasil penelitian yang telah dilakukan tentang penerapan model pembelajaran Creative Problem Solving (CPS) pada materi menerapkan etika komunikasi bisnis di kelas XI SMK Negeri 1 Banda Aceh, dapat disimpulkan bahwa: "model pembelajaran Creative Problem Solving (CPS) dapat meningkatkan hasil belajar siswa pada menerapkan etika komunikasi bisnis di kelas XI SMK Negeri 1 Banda Aceh.

\section{DAFTAR PUSTAKA}

Anwar, Saifuddin. 2005. Metodelogi. Bandung: Heksa Prakasa.

Dimyati, dan Mudjiono. 2005. Belajar dan Pembelajaran. Jakarta: Rineka Cipta.

Katz, Bernard. 1994. Turning Practical Communication into Business Power. (Terjemahan). Jakarta: PT. Pustaka Binaman Pressindo.

Nurhadi, dkk. 2003. Strategi Pembelajaran dan Penerapan dalam KBK. Malang: Universitas Negeri Malang.

Pepkin, K. L. 2004. Creative Problem Solving In Math. http://www.uh.edu/hti/cu/2004/v02/04. Diakses tanggal 11 Juli 2016

Purnama, Sani Vidia. 2007. Interaksi Siswa dalam Pembelajaran Relistik pada materi Keliling dan Luaas Persegi Panjang Di kelas IV MIN Rukoh Banda Aceh. Skripsi tidak diterbitkan. Banda Aceh: FKIPNUnsyiah.

Slameto. 2005. Belajar dan Faktor Yang Mempengaruhinya. Jakarta: Bina Aksara.

Steiner, G. 2009. "The Concept of Open Creativity: Collaborative Creative Problem Solving for Innovation Generation-a Systems Approach". Journal of Business and Management. 15, (1), 5-33. Di akses pada tanggal 01 maret 2016, dari http://scholar.google.com/citations?view_op=view_citation\&hl=

Purwanto, Djoko. 2006. Komunikasi Bisnis. Jakarta: Erlangga. 